Dicle Tıp Dergisi / Dicle Med J (2019) 46 (1) : 1 - 10

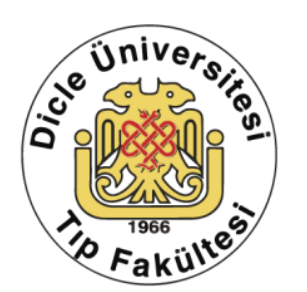

WWW.diclemedj.org

Özgün Araştırma / Original Article

\title{
Prognostic Value of Lymph Node and Spleen Activity in [18F]FDG PET-CT in Lung Adenocarcinoma and Squamous Cell Carcinoma
}

\author{
Halil Komek ${ }^{1}$, Nadiye Akdeniz² ${ }^{2}$ Zuhat Urakci ${ }^{3}$, Canan Can', Serdar Altindag5 \\ 1 Dept. of Nuclear Medicine, Saglik Bilimleri Univ Diyarbakir Gazi Yasargil Training and Research Hospital. Diyarbakir, Turkey ORCID: 0000-0001-8168-136X \\ 2 Dept. of Medical Oncology, Dicle University Diyarbakir, Turkey ORCID: 0000-0002-4597-9721 \\ 3 Dept. of Medical Oncology, Dicle University Diyarbakir, Turkey ORCID: 0000-0003-3878-988X \\ 4 Dept. of Nuclear Medicine, Saglik Bilimleri Univ Diyarbakir Gazi Yasargil Training and Research Hospital. Diyarbakir, Turkey ORCID: 0000-0002-0255-5830 \\ 5 Dept. of Nuclear Medicine, Saglik Bilimleri Univ Diyarbakir Gazi Yasargil Training and Research Hospital. Diyarbakir, Turkey ORCID: 0000-0003-1409-9956
}

Received: 02.07.2018; Revised: 01.11.2018; Accepted: 12.11.2018

\begin{abstract}
Objective: We aimed to investigate the prognostic value of primary mass, spleen and lymph node metabolic activity in [18F]FDG PET-CT as well as the prognostic value of neutrophil lymphocyte ratio (NLR) and platelet lymphocyte ratio (TLR) in patients with lung adenocarcinoma and squamous cell carcinoma.

Methods: Seventy-four patients, with pathological data, complete blood count and [18F]FDG PET-CT images, were retrospectively evaluated. Patients were grouped as lung adenocarcinoma $(n=32)$ or squamous cell carcinoma $(n=$ 42). The time between [18F]FDG PET-CT imaging and death was calculated. Standardized uptake value (SUVmax) of primary lesion was calculated (lung or mediastinum). The SUVmax value of the spleen was used as an indicator of RES activity. Metabolic activity of lymph node was calculated from the lymph node having the highest activity independent of localization.

Results: The SUVmax spleen/liver and SUVmax lymph node/liver ratios were significantly higher in the exitus subgroup of squamous cell carcinoma $(\mathrm{p}=0.025, \mathrm{p}=0.043$; respectively). The SUVmax lymph node/liver ratio was found to be a predictor for survival in squamous cell carcinoma ( $\mathrm{p}=0.019, \mathrm{OR}: 1.282$ ). The SUVmax spleen/liver and SUVmax lymph node/liver ratios were similar between subgroups of adenocancer.

Conclusions: The SUV ratios of the spleen were not a predictor for survival in both groups. The SUVmax lymph node/liver ratio was found to be a predictor for survival in squamous cell carcinoma. However, NLR and PLR were not found to be prognostic factors.
\end{abstract}

Keywords: Lung cancer, spleen activity, survival, [18F]FDG PET-CT, neutrophil lymphocyte ratio.

DOI: $10.5798 /$ dicletip.534806

Yazışma Adresi / Correspondence: Nadiye Akdeniz, Department of Medical Oncology, Dicle University Sur/ Diyarbakir, Turkey e-mail: nadiyeakdeniz21@gmail.com 


\section{Akciğer Adenokarsinom ve Skuamöz Hücreli Karsinomda [18F]FDG PET-BT 'de Lenf Nodu ve Dalak Aktivitesinin Prognostik Önemi}

\section{$\ddot{\mathbf{O} z}$}

Amaç: Akciğer adenokanser ve skuamöz hücreli kanser tanısı alan hastalarda [18F]FDG PET-BT" de primer kitle, dalak ve lenf nodunun metabolik aktivitesinin prognostik değerininin yanısıra nötrofil lenfosit oranının (NLO) ve trombosit lenfosit oranının (TLO) prognostik değerlerini araştırmayı amaçladık.

Yöntemler: Patolojik verilerine, tam kan sayımına ve [18F]FDG PET-BT görüntülerine ulaşllabilen 74 hasta retrospektif olarak değerlendirildi. Hastalar adenokarsinom $(n=32)$ veya skuamöz hücreli karsinom $(n=42)$ olarak gruplandırıldı. [18F]FDG PET-BT çekimi ile ölüme kadar geçen süre hesaplandı. Pimer lezyondan (akciğer veya mediasten ) standardized uptake value (SUVmax) hesaplandı. Dalağın SUVmax değeri, retiküloendotelyal sistem (RES) aktivitesinin bir göstergesi olarak kullanıldı. Lenf nodunun metabolik aktivitesi, lokalizasyondan bağımsız en yüksek aktiviteye sahip lenf nodundan hesaplandı.

Bulgular: Skuamöz hücreli karsinom tanısı olup ölmüş olan grupta dalak/karaciğer SUVmax oranı ve lenf nodu/ karaciğer SUVmax oranları anlamlı derecede yüksekti (sırasıyla $p=0.025, p=0.043$ ). Skuamöz hücreli karsinomda lenf nodu/karaciğer SUVmax oranının sağ kalım için belirleyici olduğu saptandı ( $\mathrm{p}=0.019$, OR: 1.282). Dalak / karaciğer SUVmax ve lenf nodu / karaciğer SUVmax oranları adenokanserin alt grupları arasında benzerdi.

Sonuç: Çalışmamızda dalaktaki SUV oranları her iki grupta da sağ kalım için bir belirteç değildi. Skuamöz hücreli karsinomda lenf nodu / karaciğer SUDmax oranının sağkalım için belirleyici bir faktör olduğu ancak NLO ve PLO' nun ise prognostik faktörler olmadığı görüldü.

Anahtar kelimeler: Akciğer kanseri, Dalak aktivitesi, Sağ kalım, [18F]FDG PET-BT, Nötrofil lenfosit oranı.

\section{INTRODUCTION}

Lung cancer is known to be the second most common cancer in both males and females and is one of the major causes of cancer-related death. There are 3 million new cases of lung cancer per year worldwide, and the 5-year overall survival rate increased to $15 \%$ in $2001^{1,2}$. The most frequently detected subtypes are adenocancer and squamous cell carcinoma, respectively.

The reticuloendothelial system (RES), also called the monocyte macrophage system, was first described by Aschoff in 1924. The spleen, liver, and bone marrow are known to be the most active reticuloendothelial organs. RES plays a major role in inflammation and immunity both against microorganisms and malignancy. Motility and phagocytic activity of reticuloendothelial cells provide destruction of unwanted material. In lung cancer, immune system activity has been observed to increase as in other malignancies and it is thought that this increased activity could be reflected in the RES.

Several studies investigated the prognostic effect of FDG uptake of mass in non-small cell lung cancer ${ }^{3-5}$. Besides primary malignancy, [18F]FDG PET may also show the presence and extent of immune response against malignant tumors in RES organs. Lee et al. showed that FDG uptake of bone marrow was associated with survival in nonsmall cell lung cancer ${ }^{6,7}$. As a part of RES, increased spleen metabolic activity may also be seen in [18F]FDG PET in patients with malignancy as a measure of increased immune activity. When combined with anatomic information obtained from computed tomography (CT), PET-CT demonstrates the extent of metabolic activity in the spleen and other RES organs ${ }^{8}$. In lung cancer, increased immune activity in the spleen can be imaged by different modalities, such as [18F]FDG PET-CT. 
Neutrophil lymphocyte ratio (NLR) and platelet lymphocyte ratio (PLR) have recently been determined as pro-inflammatory markers in several studies, which have investigated cardiovascular disorders 9,10 . Neutrophils and thrombocytes have different actions in immune defense against malignancy. It has also been suggested that these parameters could be associated with lung cancer, although the number of studies showing the associations of NLR and PLR with survival in lung cancer is limited. The aim of this study was to investigate the prognostic value of spleen and lymph node metabolic activity on [18F]FDG PET-CT imaging in patients with adenocancer and squamous cell carcinoma of the lung. It was also aimed to show the associations between NLR and PLR, and the survival of the patients.

\section{METHODS}

\section{Patient Selection and Study Design}

Data were screened of 9346 patients who were referred to our institutions, between 2012 and 2015. Evaluation was made of a total of 2637 patients who underwent an [18F]FDG PET-CT with a pre-diagnosis of pulmonary or mediastinal mass. Hypermetabolic lesions limited to the thorax were detected on the [18F]FDG PET-CT in 597 patients. According to pathological analysis, malignancy was detected in 380 patients. After exclusion of the patients with pleural and mediastinal malignancy, 264 patients with small and non-small cell lung cancer were evaluated. Of 198 patients with non-small cell lung cancer, final analysis for the study was made of 74 patients with adenocancer and squamous cell carcinoma of the lung. Inclusion criteria were histopathologically approved of adenocancer and squamous cell carcinoma of the lung. Patients had malignancy except lung cancer, autoimmune disease, use of steroids and stage IV disease were excluded. Patients were not received chemotherapy and Granulocyte
Colony-Stimulating Factor (G-CSF) before PETCT.

The study included 74 patients with pathological recordings and complete blood count measured in same week as the pathological analysis. Any patients lacking data were excluded. The data were retrieved from the electronic files of the patients and analyzed retrospectively. Patients were grouped as adenocancer $(n=32)$ or squamous cell carcinoma of the lung $(n=42)$, according to the pathological results of the biopsy/excised material. On the date of 31/10/2017, we calculated and analyzed the time between [18F]FDG PET-CT and death was calculated and analyzed. This study was approved by the local ethics committee (permit no: 028/2018). The informed consent forms was signed by the patients and by their family members or caregivers of deceased patients.

\section{Imaging procedure of [18F]FDG PET-CT}

The PET-CT images of the patients were analyzed again retrospectively. All patients underwent routine PET-CT imaging with Biograph 6 PET-CT (Siemens Medical Systems, CTI, Knoxville, TN, USA). Images were taken after at least 6 hours fasting, and glucose levels in peripheral blood in all patients were confirmed to be $\leq 140 \mathrm{mg} / \mathrm{dl}$ before the FDG injection. Approximately $5.5 \mathrm{MBq} / \mathrm{kg}$ of FDG was administered intravenously 1 hour before image acquisition. After the initial low-dose CT (Biograph 6: $80 \mathrm{~mA}, 120 \mathrm{kVp}$ ), standard PET imaging was performed from the skull base to the proximal thighs with an acquisition time of $3 \mathrm{~min} / \mathrm{bed}$ in three-dimensional mode. Images were then reconstructed using the ordered subset expectation maximization algorithm (2 iterations, 20 subsets). SUVmax values were calculated from primary lesions in the mediastinum or lung in all patients. SUVmax of the spleen was used as an indicator of RES activity. Region of interest (ROI) of $2 \mathrm{~cm}$ diameter was taken in the liver, spleen and 
pulmonary mass, and thus SUVmax values were obtained. SUV of the liver was accepted as the reference value. Metabolic activity of lymph node was calculated from the lymph node having the highest activity independent of localization. SUVmax ratios of spleen/liver, lymph node/liver, and mass/liver were calculated. The SUVmax ratio of mass/liver was calculated and standardized in all patients. The [18F]FDG PET-CT of one of the patients is shown in Figure 1.

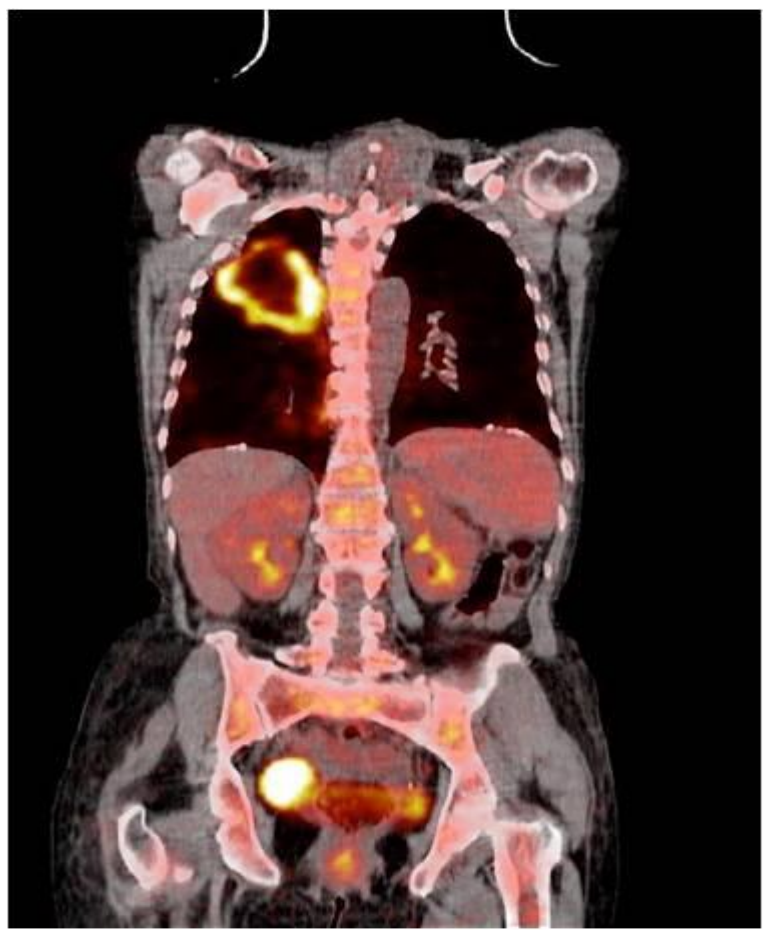

Figure1. [18F]FDG PET-CT of a 55-year old female patient with squamous cell carcinoma had a survival of 121 days. The SUVmax spleen/liver was 1.54, and SUVmax mass/liver 6.73.

In all patients, leukocyte, neutrophil, thrombocyte and lymphocyte counts were measured as number of cells per microliter in complete blood count (CBC) analyzed by automated hematology analyzer. NLR was calculated by dividing the neutrophil count by the lymphocyte count, and the PLR by dividing the platelet count by the lymphocyte count.

\section{Statistical Analysis}

Analysis of the study data was made using SPSS 24.0 software (IBM Corporation, Armonk, New York, United States). Conformity of the data to normal distribution was evaluated with the Shapiro-Wilk test, and homogeneity of variance with the Levene test. The comparison of the quantitative data of two independent groups was made using the Independent-Samples ttest together with Bootstrap results, and the Mann-Whitney U (Exact) test together with Monte Carlo results. Categorical variables were compared with the application of the Pearson Chi-Square test and the Fisher Exact testwith the Monte Carlo stimulation technique. To evaluate the effects of prognostic variables on survival, Cox Regression analysis was used with the Enter method. Quantitative variables were shown in the tables as mean \pm standard deviation (SD) and median range (maximumminimum) values, and categorical variables as number (n) and percentage (\%) in tables. Variables were analyzed at $95 \%$ confidence level, and a value of $\mathrm{p}<0.05$ was accepted as statistically significant.

\section{RESULTS}

Mean age $53.11 \pm 13.19$ and $59.26 \pm 12.77$ in alive and exitus subgroups of adenocancer. It was $61 \pm 12.22$ and $62.73 \pm 10.37$ in alive and exitus subgroups of squamous cell cancer. Percentage of male patients was $88.9 \%$ and $60.9 \%$ in alive and exitus subgroups of adenocancer, $77.8 \%$ and $84.8 \%$ in alive and exitus subgorups of squamous cell cancer. No differences were determined in mean age and distribution of gender in the alive and exitus subgroups in the adenocancer and squamous cell cancer groups. The distribution of higher and lower thrombocyte, neutrophil and lymphocyte groups was similar in the alive and exitus subgroups of adenocancer and squamous cell cancer groups. Neutrophil, lymphocyte and thrombocyte counts were similar in both subgroups. NLR was similar in both subgroups of adenocancer, but was significantly higher in the exitus subgroup of squamous cell carcinoma compared to the alive group $(p=0.039)$. No differences were found between the alive and exitus subgroups in the 
adenocancer and squamous cell carcinoma groups in respect of NLR and PLR. SUVmax ratios of mass/liver were similar in both subgroups in the adenocancer and squamous cell carcinoma groups. SUVmax spleen/liver and SUVmax lymph/liver ratios were significantly higher in the exitus subgroup of squamous cell carcinoma ( $\mathrm{p}=0.025, \mathrm{p}=0.043$; respectively). (Table 1, Figure 2, Figure 3, Figure 4). Mean survival rates were $974 \pm 243.45$ days in alive group, and $481.16 \pm 457.94$ days in exitus group.

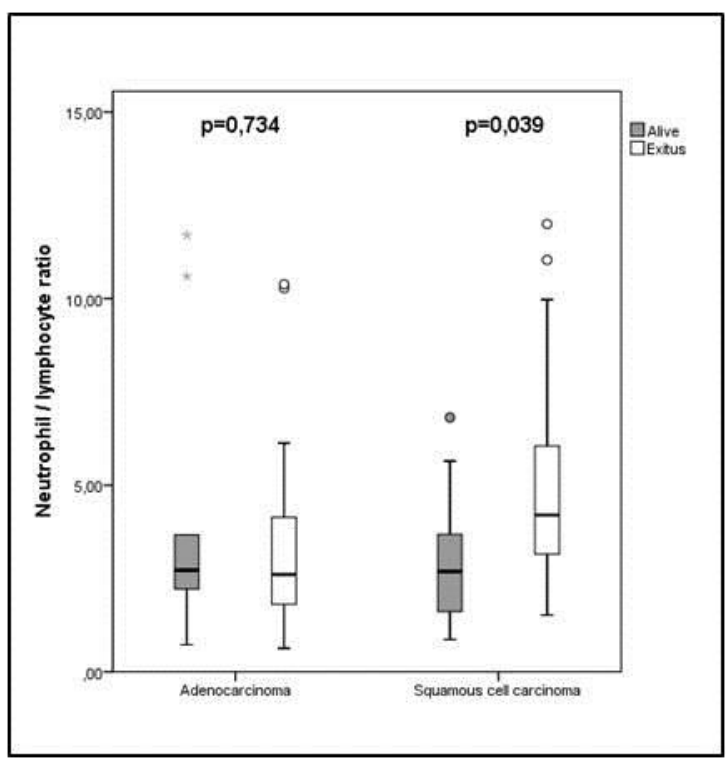

Figure 2. Comparison of NLR between subgroups.

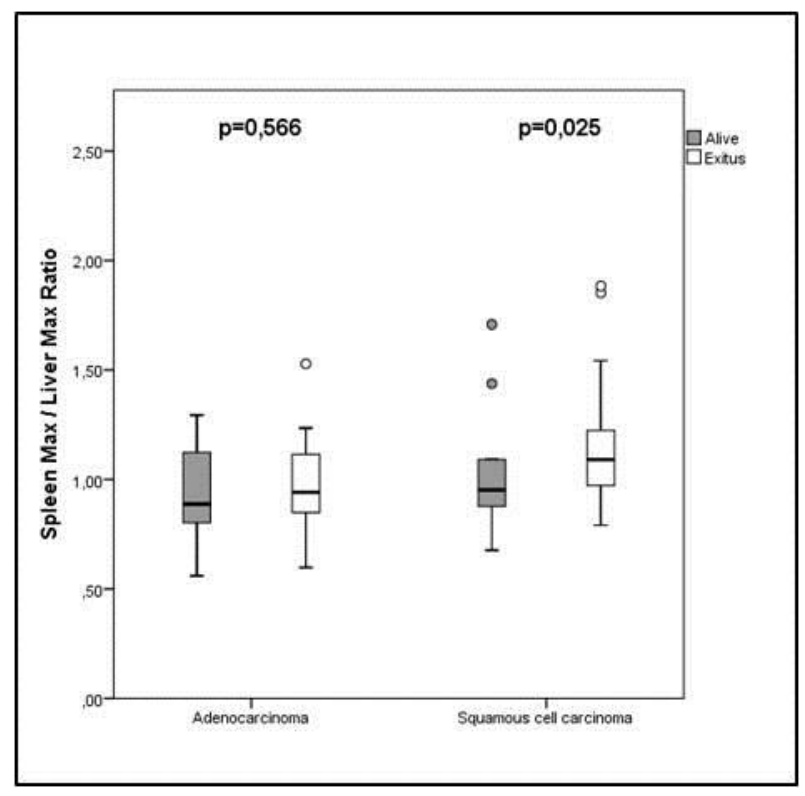

Figure 3. Comparison of SUVmean spleen/liver ratio between subgroups.

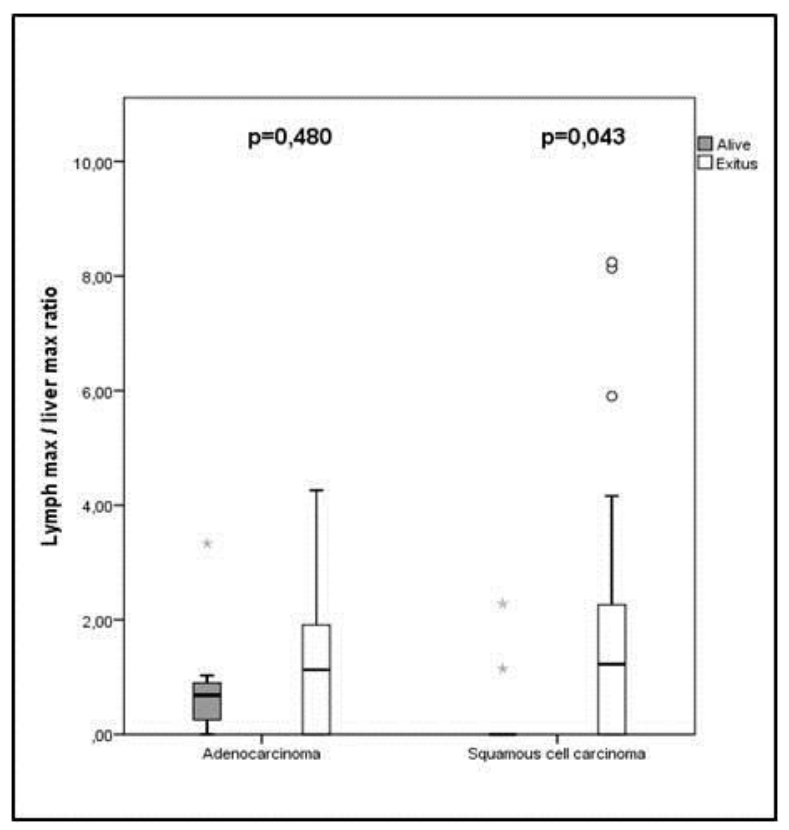

Figure 4. Comparison of SUVmax lymph node/liver ratio

The method of taking pathological specimens and the distribution of pathological lymph nodes are shown in Table 2.

In the squamous cell carcinoma group, decreased NLR increased survival 1.122-fold but it was non-significant ( $\mathrm{p}=0.140$, OR:1.122). A lower SUVmax spleen/liver ratio was found 
to be a non-significant predictor of survival in SUVmax lymph/liver ratio was found to be a the squamous cell carcinoma $(\mathrm{p}=0.249$, predictor for survival in the squamous cell OR:2.247) group ( $\mathrm{p}=0.249$, OR:2.247). The carcinoma $(\mathrm{p}=0.019,0 \mathrm{R}: 1.282)$ (Table 3).

Table 1. Basic demographic characteristics and laboratory values of the patients.

\begin{tabular}{|c|c|c|c|c|c|c|}
\hline & \multicolumn{2}{|c|}{ Adenocancer } & \multirow{3}{*}{$\mathbf{P}$} & \multicolumn{2}{|c|}{ Squamous cell carcinoma } & \multirow{3}{*}{$\mathbf{P}$} \\
\hline & Alive & Exitus & & Alive & Exitus & \\
\hline & $(\mathbf{n}=9)$ & $(\mathbf{n}=\mathbf{2 3})$ & & $(\mathbf{n}=9)$ & $(n=33)$ & \\
\hline Age (years) & $53.11 \pm 13.19 /(23-73)$ & $59.26 \pm 12.77 /(27-80)$ & 0.211 & $61 \pm 12.22 /(45-78)$ & $62.73 \pm 10.37 /(40-81)$ & 0.687 \\
\hline \multicolumn{7}{|l|}{ Gender } \\
\hline Male & $8(88.9)$ & $14(60.9)$ & 0.210 & $7(77.8)$ & $28(84.8)$ & 0.472 \\
\hline Female & $1(11.1)$ & $9(39.1)$ & & $2(22.2)$ & $5(15.2)$ & \\
\hline \multicolumn{7}{|l|}{ Thrombocyte } \\
\hline$<400$ & $8(88.9)$ & $21(91.3)$ & 1 & $8(88.9)$ & $21(63.6)$ & 0.232 \\
\hline$>400$ & $1(11.1)$ & $2(8.7)$ & & $1(11.1)$ & $12(36.4)$ & \\
\hline \multicolumn{7}{|l|}{ Neutrophil } \\
\hline$<6.5$ & $5(55.6)$ & $15(65.2)$ & 0.696 & $6(66.7)$ & $15(45.5)$ & 0.454 \\
\hline$>6.5$ & $4(44.4)$ & $8(34.8)$ & & $3(33.3)$ & $18(54.5)$ & \\
\hline \multicolumn{7}{|l|}{ Lymphocyte } \\
\hline$<3.5$ & $8(88.9)$ & $21(91.3)$ & 1 & $8(88.9)$ & $32(97.0)$ & 0.387 \\
\hline$>3.5$ & $1(11.1)$ & $2(8.7)$ & & $1(11.1)$ & $1(3.0)$ & \\
\hline \multicolumn{7}{|l|}{$\begin{array}{l}\text { SUVmax } \\
\text { spleen/liver }\end{array}$} \\
\hline$<1$ & $6(66.7)$ & $14(60.9)$ & 1 & $5(55.6)$ & $10(30.3)$ & 0.242 \\
\hline$>1$ & $3(33.3)$ & $9(39.1)$ & & $4(44.4)$ & $23(69.7)$ & \\
\hline $\begin{array}{l}\text { SUVmax } \\
\text { mass/liver }\end{array}$ & $5.21 \pm 4.21$ & $4.01 \pm 2.25$ & 0.460 & $4.57 \pm 2.28$ & $5.70 \pm 2.89$ & 0.218 \\
\hline Thrombocyte & $299.11 \pm 76.15$ & $281.09 \pm 92.06$ & 0.555 & $285.67 \pm 73.74$ & $342.12 \pm 125.13$ & 0.083 \\
\hline Neutrophil & $5.76(4.04-22.99)$ & $5.50(1.78-10.95)$ & 0.691 & $4.88(1.65-8.58)$ & $7.31(1.86-86.40)$ & 0.116 \\
\hline Lymphocyte & $2.49 \pm 1.38$ & $2.24 \pm 0.96$ & 0.604 & $1.41(1.02-5.46)$ & $1.61(0.55-7.20)$ & 0.945 \\
\hline NLR & $2.72(0.73-11.70)$ & $2.61(0.63-13.52)$ & 0.734 & $2.69(0.87-6.81)$ & $4.20(1.52-12)$ & 0.039 \\
\hline PLR & $156.62(52.78-322.81)$ & $123.71(53.72-580.25)$ & 0.769 & $191.06 \pm 118.11$ & $232.21 \pm 120.56$ & 0.345 \\
\hline $\begin{array}{l}\text { SUVmax } \\
\text { spleen/liver }\end{array}$ & $0.89(0.56-1.29)$ & $0.94(0.60-2.19)$ & 0.566 & $0.95(0.68-1.71)$ & $1.09(0.79-1.88)$ & 0.025 \\
\hline $\begin{array}{l}\text { SUVmax } \\
\text { lymph/liver }\end{array}$ & $0.68(0-3.33)$ & $1.13(0-4.26)$ & 0.480 & $0(0-2.28)$ & $1.23(0-8.24)$ & 0.043 \\
\hline Survival & $754(694-994)$ & $433(21-1.246)$ & 0.005 & $1.001(801-1.449)$ & $288(40-2.131)$ & $<0.001$ \\
\hline
\end{tabular}

Independent samples t test(Bootstrap) / Mann Whitney U Test (Monte Carlo) / FisherExact Test(Exact) / Pearson Chi-Square test(Monte Carlo) / Data are presented as Mean \pm SD.(Standard deviation), Median(Minimum-Maximum) and number (n) and percentage (\%).

\section{DISCUSSION}

In several studies, [18F]FDG PET imaging has been shown to be an important tool for detecting clinical stage, therapeutic response, metastases and recurrence in patients with non-small cell lung cancer11-14. Motono et al analyzed 58 patients with adenocancer and 20 
patients with squamous cell cancer of the lung in terms of predictive value in detecting recurrence ${ }^{15}$. The SUVmax value of the mass was found to be a significant predictor for recurrence (disease free survival) in adenocancer but not in squamous cell cancer. In other studies, the SUVmax value has been found to be a predictive factor of survival in patients with non-small cell lung cancer ${ }^{16-18}$. In the current study, the SUVmax mass/liver ratio was not determined to be of predictive value in the survival of patients with either squamous cell carcinoma or adenocancer of the lung. SUVmax is used as a semi-quantitative measurement tool showing FDG uptake in tumor cells and is affected by the metabolic status of the patient. Different PET scanners also show different SUVmax values making standardization difficult. To achieve a standardized value in this study, the liver was used as a correction constant. However, SUVmax of the mass was not determined to be of any predictive value for survival. Jin et al investigated patients with advanced stage nonsmall cell lung cancer to determine the prognostic value of SUVmax change in dual time point [18F]FDG PET ${ }^{19}$. The SUVmax change between the 1 st and 2 nd hours of [18F]FDG injection was shown to be a prognostic factor in progression free and overall survival. In the current study, imaging was acquired at the 1st hour only.

Table 2. The method of taking specimen and distribution of pathological lymph nodes.

\begin{tabular}{|c|c|c|c|c|c|c|c|c|}
\hline & \multicolumn{4}{|c|}{ Adenocancer } & \multicolumn{4}{|c|}{ Squamous cell cancer } \\
\hline & \multicolumn{2}{|c|}{ Alive } & \multicolumn{2}{|c|}{ Exitus } & \multicolumn{2}{|c|}{ Alive } & \multicolumn{2}{|c|}{ Exitus } \\
\hline & $\mathbf{n}$ & $\%$ & $\mathbf{n}$ & $\%$ & $\mathbf{n}$ & $\%$ & $\mathbf{n}$ & $\%$ \\
\hline \multicolumn{9}{|l|}{ Pathological analysis } \\
\hline Biopsy & 0 & $0.0 \%$ & 3 & $13.0 \%$ & 1 & $11.1 \%$ & 5 & $15.2 \%$ \\
\hline Fiberoptic bronchoscopy & 0 & $0.0 \%$ & 4 & $17.4 \%$ & 1 & $11.1 \%$ & 10 & $30.3 \%$ \\
\hline Lavage & 0 & $0.0 \%$ & 4 & $17.4 \%$ & 1 & $11.1 \%$ & 2 & $6.1 \%$ \\
\hline Lobectomy & 2 & $22.2 \%$ & 0 & $0.0 \%$ & 1 & $11.1 \%$ & 0 & $0.0 \%$ \\
\hline Pneumectomy & 0 & $0.0 \%$ & 1 & $4.3 \%$ & 2 & $22.2 \%$ & 0 & $0.0 \%$ \\
\hline Resection & 0 & $0.0 \%$ & 0 & $0.0 \%$ & 1 & $11.1 \%$ & 0 & $0.0 \%$ \\
\hline Thoracotomy & 1 & $11.1 \%$ & 1 & $4.3 \%$ & 0 & $0.0 \%$ & 1 & $3.0 \%$ \\
\hline True-cut & 6 & $66.7 \%$ & 10 & $43.5 \%$ & 2 & $22.2 \%$ & 15 & $45.5 \%$ \\
\hline \multicolumn{9}{|l|}{ Lymph node localization } \\
\hline None & 2 & $22.2 \%$ & 9 & $39.1 \%$ & 6 & $66.7 \%$ & 13 & $39.4 \%$ \\
\hline Ipsilateral hilar & 1 & $11.1 \%$ & 1 & $4.3 \%$ & 0 & $0.0 \%$ & 0 & $0.0 \%$ \\
\hline Ipsilateral other side & 6 & $66.7 \%$ & 5 & $21.7 \%$ & 2 & $22.2 \%$ & 10 & $30.3 \%$ \\
\hline $\begin{array}{l}\text { Ipsilateral supraclavicular and } \\
\text { Contralateral lymph nodes }\end{array}$ & 0 & $0.0 \%$ & 8 & $34.8 \%$ & 1 & $11.1 \%$ & 10 & $30.3 \%$ \\
\hline
\end{tabular}

Park et al investigated the influence of neoadjuvant therapy on SUVmax value in 578 patients with non-small cell lung cancer $^{20}$. It was determined that in the non-neoadjuvant therapy group, lymph node SUVmax was significantly associated with disease-free and overall survival. In the current study, increased SUVmax lymph node/liver ratio was found to be associated with decreased survival in both the squamous cell cancer group. However, we calculated SUVmax of the lymph node having 
the highest metabolic activity independent of localization. In a study by Park et al, an association of SUVmax with survival was observed both in positive N1 and N2 lymph nodes $^{20}$. As a part of RES, increased metabolic activity could be expected in lymph nodes on a PET imaging. However, the lymph nodes from which SUVmax was calculated in the current study were pathologically involved lymph nodes. Therefore, the cause of increased activity in these lymph nodes could be accepted as metastases. Hence, the prognostic value of SUVmax in lymph nodes was not an unexpected finding.

Table 3. Prognostic factors in predicting survival.

\begin{tabular}{|c|c|c|c|c|c|c|c|}
\hline & \multirow{2}{*}{ B (SE) } & \multirow{2}{*}{ P Value } & \multirow{2}{*}{$\begin{array}{l}\text { Odss } \\
\text { Ratio }\end{array}$} & \multicolumn{2}{|c|}{ 95,0\% CI for Odss Ratio } & \multirow{2}{*}{$\frac{3 \text { / } 5 \text { years Survival rates }}{\%(\mathrm{SE})}$} & \multirow{2}{*}{$\begin{array}{c}\text { Baseline } \\
\text { - Hazard } \\
(\%)\end{array}$} \\
\hline & & & & Lower & Upper & & \\
\hline \multicolumn{8}{|l|}{ Squamous cell carcinoma } \\
\hline NLR & $0.115(0.078)$ & 0.140 & 1.122 & 0.963 & 1.306 & & \\
\hline SUVmax spleen/liver & $0.810(0.703)$ & 0.249 & 2.247 & 0.567 & 8.908 & $27.5(0.704) / 12.1(0.012)$ & 0.3 \\
\hline SUVmax lymph/liver & $0.249(0.106)$ & 0.019 & 1.282 & 1.041 & 1.579 & & \\
\hline
\end{tabular}

Cox Regression-Enter Model / B: Regression Cofficient SE.: Standard Error CI.: Confidence Interval

In this study, the SUVmax spleen/liver ratio was found to be higher in the exitus subgroup of the patients with squamous cell cancer. Nevertheless, it was not determined as a predictor for survival in either squamous cell or adenocancer. The spleen is known to be the second largest lymphoid organ and has an important role in host defence, contributing to cellular and humoral immunity. Monocytes in circulation are converted into macrophages residing in red pulp, providing phagocytic activity of the spleen by slow blood flow. Hence, it allows for phagocytosis of cellular debris and senescent cells ${ }^{21}$. A few studies have shown that increased splenic FDG uptake in PET imaging could be observed in cancer patients 22 24. Unlike pathological lymph nodes involved in squamous lung cancer, increased metabolic activity in the spleen might result from increased activity of the monocyte-macrophage system against malignancy rather than from direct metastases. In some studies, increased splenic FDG uptake has been found to be associated with anemia, infections, and cytokines ${ }^{22-24}$. Similarly, in a study by Bural et al, the SUVmean value of the spleen was significantly higher on PET imaging of lung cancer patients compared to patients with benign pulmonary nodule ${ }^{25}$. This difference was attributed to increased immune defence against malignancy. Therefore, it may be proposed that the SUV value of the spleen may not be clearly associated with prognosis of the patient. Finally, in the current study, the SUVmax values of the spleen were not determined to be predictive of survival. Aktaş et al compared 15 lung cancer patients with diffuse splenic FDG uptake with 12 other lung cancer patients ${ }^{26}$. No significant differences were found in terms of infection or distant metastases. In that study, the bone marrow SUV values were similar in both groups. Komek et al investigated the associations of PET parameters of primary cancer and RES with pathological characteristics of the mass, and with hematological parameters ${ }^{27}$. They could not find any associations between benign and malign masses, or squamous and nonsquamous cancer in terms of SUV ratios of spleen or bone marrow. Bone marrow is also one of the RES organs like the spleen, although metabolic activity may not be similar in bone marrow and spleen in different cancers. It might be useful to calculate bone marrow SUV in comparison with 
the spleen. However, no analysis was made of the SUV values of bone marrow in the current study. Differences in the predictive value of SUV values of the lymph node or spleen may be explained by both differential activation of immunity in different RES organs and metastases in lymph nodes but not in the spleen.

In a previous study, NLR and PLR have been found to be associated with lung cancer compared to a control group, but did not differ between subgroups of lung cancer patients ${ }^{28}$. In some studies, NLR and PLR have also been shown to be a predictor for survival in cancer patients including lung cancer ${ }^{29-31}$. Zhang et al showed that platelet count and NLR were associated with overall survival and diseasefree survival in 1238 patients with non-small cell lung cancer ${ }^{30}$. Similarly, Unal et al revealed that there were significant associations between increased NLR and PLR, and decreased overall survival in 94 patients with non-small cell lung cancer ${ }^{31}$. The results of the current study showed that NLR was higher in the exitus subgroup of the squamous cell carcinoma group. However, in contrast to previous studies, NLR was not determined as a predictor for survival in regression analysis.

\section{Limitations}

The study design was a retrospective cohort, and the sample size was relatively small. However, few studies have investigated the prognostic effect of the SUV value of the spleen in adenocancer and squamous cell carcinoma of the lung. Further prospective studies including a larger sample size will clarify this issue. No evaluation was made of pathological factors other than diagnosis, such as pathological examination findings of lymph node or other RES organs. Bone marrow is one of the RES organs, and therefore evaluation of SUV of bone marrow could have been included in the analysis. No cut-off value was calculated for SUV values with ROC analysis, and finally the patients were not separated into subgroups according to the presence of metastases, or receiving adjuvant or neoadjuvant chemotherapy.

\section{CONCLUSION}

NLR and PLR were not found to be prognostic factors. The SUV ratios of the spleen were not predictive of survival in both groups. The SUVmax lymph node/liver ratio was found to be a predictor for survival in the squamous cell carcinoma group. As the number of studies analyzing the prognostic effect of the SUV value of the spleen is limited, there is a need for further studies.

Declaration of Conflicting Interests: The authors declare that they have no conflict of interest.

Financial Disclosure: No financial support was received.

\section{REFERENCES}

1. Vansteenkiste J, Fischer BM, Dooms C, et all. Positron emission tomography in prognostic and therapeutic assessment of lung cancer: systematic review. Lancet Oncol. 2004; 5: 531-40.

2. de Geus-Oei LF, van Krieken JH, Aliredjo RP et all. Biological correlates of FDG uptake in non-small cell lung cancer. Lung Cancer. 2007; 55: 79-87.

3. chuurbiers OC, Meijer TW, Kaanders JH, et all. Glucose metabolism in NSCLC is histology-specific and diverges the prognostic potential of 18FDG-PET for adenocarcinoma and squamous cell carcinoma.. J Thorac Oncol. 2014; 9: 1485-93.

4. Lee HY, Lee HJ, Kim YT, et all. Value of combined interpretation of computed tomography response and positron emission tomography response for prediction of prognosis after neoadjuvant chemotherapy in nonsmall cell lung cancer. J Thorac Oncol. 2010; 5: 497503.

5. Nair VS, Krupitskaya Y, Gould MK. Positron emission tomography $18 \mathrm{~F}$ fluorodeoxyglucose uptake and prognosis in patients with surgically treated, stage I non small cell lung cancer: a systematic review. J Thorac Oncol. 2009;12: 1473-9.

6. Lee JW, Na JO, Kang DY, Lee SY, Lee SM. Prognostic Significance of FDG Uptake of Bone Marrow on PET/CT in Patients With Non-Small-Cell Lung Cancer After 
Curative Surgical Resection. Clin Lung Cancer. 2017; 18: 198-206.

7. Prévost $S$, Boucher L, Larivée $P$, et all. Bone marrow hypermetabolism on 18F-FDG PET as a survival prognostic factor in non small cell lung cancer. 2006; 4:559-65.

8. Blebea JS, Houseni M, Torigian DA, et all. Structural and functional imaging of normal bone marrow and evaluation of its age-related changes. Semin Nucl Med. 2007; 37:185-94.

9. Wang J, Jia $\mathrm{Y}$, Wang $\mathrm{N}$, et all. The clinical significance of tumor-infiltrating neutrophils and neutrophil-to- CD8+ lymphocyte ratio in patients with resectable esophageal squamous cell carcinoma. J Transl Med. 2014; $12: 7$.

10. Xue P, Kanai M, Mori $Y$, et al. Neutrophil-tolymphocyte ratio for predicting palliative chemotherapy outcomes in advanced pancreatic cancer patients. Cancer Med. 2014; 3: 406-415.

11. de Geus-Oei LF, van der Heijden H, Corstens F, et all. Predictive and prognostic value of FDG-PET in nonsmall-cell lung cancer. Cancer. 2007; 110: 1654-64.

12. Al-Jahdali H, Khan AN, Loutfi S, et all. Guidelines for the role of FDG-PET/CT in lung cancer management. J Infect Public Health. 2012; 5: 35-40.

13. Liu NB, Zhu L, Li MH, et all. Diagnostic value of $18 \mathrm{~F}$ FDG PET/CT in comparison to bone scintigraphy, CT and 18F-FDG PET for the detection of bone metastasis. Asian Pac J Cancer Prev. 2013; 14: 3647-52.

14. Mutlu H, Buyukcelik A, Erden A, et all. Staging with PET-CT in patients with locally advanced nonsmall cell lung cancer is superior to conventional staging methods in terms of survival. Asian Pac J Cancer Prev. 2013; 14: 3743-6.

15. Motono N, Ueno M, Tanaka M, et all. Differences in the prognostic significance of The SUVmax between patients with resected pulmonary Adenocarcinoma and squamous cell carcinoma. Asian Pac J Cancer Prev. 2014; 15: 10171-4.

16. Vansteekiste JF, Stroobants SG, Dupont PJ, et all. Prognostic importance of the standardized uptake value on 18F-fluoro-2-deoxy-glucose-positron emission tomography scan in non-small-cell lung cancer. An analysis of 125 cases. J Clin Oncol. 1999; 17: 3201-6.

17. Patz EF Jr, Connolly J, Herndon J. Prognostic value of thoracic FDG PET imaging after treatment for nonsmall cell lung cancer. AJR. 2000; 174: 769-74.

18. Higashi K, Ueda Y, Arisaka Y, et all. 18F-FDG uptake as a biologic prognostic factor for recurrence in patients with surgically resected non-small cell lung cancer. J Nucl Med. 2002; 43: 39-45.

19. Jin F, Zhu H, Fu Z, Kong L, Yu J. Prognostic value of the standardized uptake value maximum change calculated by dual-time-point (18)F-fluorodeoxyglucose positron emission tomography imaging in patients with advanced non-small-cell lung cancer. Onco Targets Ther. 2016; 19: 2993-9.

20. Park JK, Kim JJ, Moon SW. Variations in positron emission tomography-computed tomography findings for patients receiving neo adjuvant and non-neo adjuvant therapy for non-small cell lung cancer. J Thorac Dis. 2017; 2: 344-54.

21. Kraal G. Cells in the marginal zone of the spleen. Int Rev Cytol. 1992; 132: 31-74.

22. Nam HY, Kim SJ, Kim IJ, et all. The clinical implication and prediction of diffuse splenic FDG uptake during cancer surveillance. Clin Nucl Med. 2010; 35: 759-63.

23. Pak K, Kim SJ, Kim IJ, et all. Impact of cytokines on diffuse splenic 18F-fluorodeoxyglucose uptake during positron emission tomography/computed tomography. Nucl Med Commun. 2013; 34: 64-70.

24. Salaun PY, Gastinne T, Bodet-Milin C, et all. Analysis of 18F-FDG PET diffuse bone marrow uptake and splenic uptake in staging of Hodgkin's lymphoma: a reflection of disease infiltration or just inflammation? Eur J Nucl Med Mol Imaging. 2009; 36: 1813-21.

25. Bural GG, Torigian DA, Chen W, et all. Increased $18 \mathrm{~F}$ FDG uptake within the reticuloendothelial system in patients with active lung cancer on PET imaging may indicate activation of the systemic immune response. Hell J Nucl Med. 2010; 13: 23-5.

26. Aktaş GE, Sarıkaya A, Demir SS. Diffusely Increased Splenic Fluorodeoxyglucose Uptake in Lung Cancer Patients. Turk Thorac J. 2017; 18: 6-10.

27. Komek H, Altindag S and Can C. Association of PET Scan Parameters of Pulmonary Masses and Reticuloendothelial System with Hematologic Parameters. J Nucl Med Radiat Ther. 2017; 8: 2.

28. Nikolić I, Kukulj S, Samaržija M et all. Neutrophil-tolymphocyte and platelet-to-lymphocyte ratio help identify patients with lung cancer, but do not differentiate between lung cancer subtypes. Croat Med J. 2016; 3: 287-92.

29. Gun XB, Tian T, Tian XJ et all. Prognostic significance of neutrophil-to-lymphocyte ratio in non-small cell lung cancer: ameta-analysis. Sci Rep. 2015; 5: 12493.

30. Zhang H, Zhang L, Zhu K et all. Prognostic significance of combination of preoperative platelet count and neutrophil-lymphocyte ratio (COP-NLR) in patients with non-small cell lung cancer: based on a large cohort study. PLoS ONE. 2015; 10: e0126496.

31. Unal D, Eroglu C, Kurtul N, et all. Are neutrophil/lymphocyte and platelet/lymphocyte rates in patients with non-small cell lung cancer associated with treatment response and prognosis? Asian Pac J Cancer Prev. 2013; 14: 5237-42. 